Herz 2016 · 41:173-174

DOI 10.1007/s00059-016-4419-3

Published online: 25 February 2016

(c) Springer Medizin Verlag 2016

CrossMark

\author{
D. Tschöpe ${ }^{1,4} \cdot$ N. Marx ${ }^{2} \cdot$ R. Dörr ${ }^{3,4}$ \\ 'Herz- und Diabeteszentrum NRW, Universitätsklinikum der Ruhr-Universität Bochum, Bad Oeynhausen, \\ Deutschland \\ ${ }^{2}$ Medizinische Klinik I, Universitätsklinikum Aachen, RWTH Aachen, Aachen, Deutschland \\ ${ }^{3}$ PRAXISKLINIK HERZ UND GEFÄSSE, Akademische Lehrpraxisklinik der TU Dresden, Dresden, Deutschland \\ ${ }^{4}$ Stiftung „Der herzkranke Diabetiker" in der Deutschen Diabetes-Stiftung
}

\title{
Diabetes and the heart - the battle is not lost yet!
}

metabolism driven cardiomyopathy to new therapeutic options in addition to early metabolic control.

After ACCORD [2], VADT [3], ADVANCE [4], or ORIGIN [5], addressing the effect of intensive glycaemic control on cardiovascular (CV) events, various cardiovascular outcome trials (CVOTs) have been published on incretin-based antidiabetic drugs as add-ons to guideline-based routine care (SAVOR [6], EXAMINE [7], ELIXA [8], TECOS [9]). These trials compared a certain antidiabetic agent to placebo aiming for glycaemic equipoise and showed CV safety of the respective drugs (the primary aim of these studies), but could not demonstrate a CV benefit. Good news came from the EMPA-REG Outcome trial [10], which documented for the first time a significant survival benefit for the SGLT2 inhibitor empagliflozin versus placebo in a high-risk population of patients with type 2 diabetes, opening new perspectives for the therapy of these patients. Here, we are reassured with a robust outcome improvement not knowing what efficacy component drives the clinical benefit. Most probably, metabolic and volume control act together synergistically. Guntram Schernthaner provides us with an updated review of our oral possibilities with the challenging perspective beyond metformin.

Down the line with the guideline goals for lipids, particularly LDL-cholesterol, which at present appears as the predominant denominator of vascular health from an epidemiological point of view, the introduction of the new principle of PCSK9 inhibition could turn out to be a novel tool for target-value achievement, particularly in the population of patients with diabetes and coronary artery disease. Klaus Parhofer discusses the recent data from the RCTs with the available antibody-based components.

The everlasting challenge of finding the best strategy to treat patients with manifest, complex multi-vessel coronary artery disease by means of interventions is addressed by Stephan Windecker with the guideline mandate to define a role for catheter-based interventions versus surgery after the FREEDOM trial [11].

Altogether, the problem with a growing number of clinical manifestations remains with a steep increase in the number of individuals affected by diabetes and coronary disease conditions and related comorbidities, such as kidney or neurological deficits. However, consequent development of drugs addressing the pathophysiology and clinical research for documenting mode and strength of clinical interventions allows for a smoother clinical judgement - the battle appears not to be lost yet!

\section{Corresponding address}

Prof. Dr. med. Dr. h.c. D. Tschöpe

Herz- und Diabeteszentrum NRW, Universitätsklinikum der Ruhr-Universität Bochum

Georgstr. 11, 32545 Bad Oeynhausen,

Deutschland

diethelm.tschoepe@rub.de

Conflicts of interest. D. Tschöpe, N. Marx and R. Dörr

state that there are no conflicts of interest. prehensive overview of heart failure in diabetes mellitus starting from the 


\section{References}

1. Rydén L, GrantPJ, Anker SD, Task Force on diabetes, pre-diabetes, and cardiovascular diseases of the European Society of Cardiology (ESC), European Association for the Study of Diabetes (EASD) et al (2013) ESC guidelines on diabetes, prediabetes, and cardiovascular diseases developed in collaboration with the EASD. Eur Heart J 34:3035-3087

2. Gerstein HC, Miller ME, Byington RP, ACCORD Study Group et al (2008) Effects of intensive glucose lowering in type 2 diabetes. $\mathrm{N}$ Engl J Med 358:2545-2559

3. Duckworth W, Abraira C, Moritz T, VADT Investigators et al (2009) Glucose control and vascular complications in veterans with type 2 diabetes. $\mathrm{N}$ Engl J Med 360:129-139

4. Patel A, MacMahon S, Chalmers J, ADVANCE Collaborative Group et al (2008) Intensive blood glucose control and vascular outcomes in patients with type 2 diabetes. N Engl J Med 358:2560-2572

5. Gerstein HC, Bosch J, Dagenais GR, ORIGIN Trial Investigators et al (2012) Basal insulin and cardiovascular and other outcomes in dysglycemia. NEngl J Med 367:319-328

6. Scirica BM, Bhatt DL, Braunwald E, SAVOR-TIMI 53 Steering Committee and Investigators et al (2013) Saxagliptin and cardiovascular outcomes in patients with type 2 diabetes mellitus. NEngl J Med 369:1317-1326

7. White WB, Cannon CP, Heller SR, EXAMINE Investigators et al (2013) Alogliptin after acute coronary syndrome in patients with type 2 diabetes. NEngl J Med 369:1327-1335

8. Pfeffer MA, Claggett B, Diaz R, ELIXA Investigators et al (2015) Lixisenatide in patients with type 2 diabetes and acute coronary syndrome. N Engl J Med 373:2247-2257

9. Green JB, Bethel MA, Armstrong PW, TECOS Study Group et al (2015) Effect of Sitagliptin on cardiovascular outcomes in type 2 diabetes. NEngl JMed 373:232-242

10. Zinman B, Wanner C, Lachin JM, EMPA-REG OUTCOME Investigators et al (2015) Empagliflozin, cardiovascular outcomes, and mortality in type 2 diabetes. NEngl J Med 373:2117-2128

11. Farkouh ME, Domanski M, Sleeper LA, FREEDOM Trial Investigators et al (2012) Strategies for multivessel revascularization in patients with diabetes. NEngl J Med 367:2375-2384

\section{Körpergröße beeinflusst Risiko für Herz-Kreislauf- Erkrankungen, Diabetes und Krebs}

Verschiedene Studien zeigten bereits, dass große im Vergleich zu kleinen Menschen ein erniedrigtes Risiko für Herz-Kreislauf-Erkrankungen und Typ-2-Diabetes haben, aber ein erhöhtes Risiko haben, an Krebs zu erkranken. Pro 6,5 cm Körpergröße sinkt das Risiko für kardiovaskuläre Sterblichkeit um 6 Prozent, dafür steigt aber die Krebsmortalität um 4 Prozent. Wissenschaftler aus Tübingen, Potsdam und Boston gehen nun anhand neuer Daten davon aus, dass eine zunehmende Körpergröße Ausdruck eines Überangebots von hochkalorischer Nahrung reich an tierischem Eiweiß in verschiedenen Stadien des Wachstums ist. Dadurch könnte bereits im Mutterleib eine lebenslange Programmierung stattfinden, die bislang vor allem für das insulin like growth factor 1 und 2 sowie das IGF-1/2-System belegt werden konnte. Eine Aktivierung dieses Systems führt u.a. dazu, dass der Körper empfindlicher wird für die Wirkung des Insulins und, dass der Fettstoffwechsel günstig beeinflusst wird. Entsprechend zeigen die neuen Daten, dass große Menschen insulinempfindlicher sind und einen geringeren Fettgehalt in der Leber haben, was ihr niedriges Risiko für Herz-Kreislauf-Erkrankungen und Typ-2-Diabetes mit erklären kann. Aber gerade diese Aktivierung des IGF-1/2-System und anderer Signalwege könnte zu einem erhöhten Risiko für bestimmte Krebsarten führen, indem das Zellwachstum dauerhaft gefördert wird.

Stefan N, Häring, H-U, Hu FB, Schulze MB (2016) Divergent associations of height with cardiometabolic disease and cancer: epidemiology, pathophysiology, and global implications. Lancet Diabetes \& Endocrinology (epub ahead of print) http://dx.doi.org/10.1016/S22138587(15)00474-X

Quelle: Deutsches Zentrum für Diabetesforschung (www.dzd-ev.de)

\section{Gleiche Mutationen bei schwangerschaftsbedingter Herzschwäche und Herz- muskelerkrankung}

Die schwangerschaftsbedingte

Herzschwäche (peripartale Kardiomyopathie, PPCM) weist ähnliche klinische Merkmale auf wie die häufig auftretende Herzmuskelerkrankung (idiopathische dilatative Kardiomyopathie, iDCM), die durch Mutationen in zahlreichen Genen verursacht wird.

Die Arbeitsgruppe um Prof. Dr. HilfikerKleiner, Klinik für Kardiologie und Angiologie der Medizinischen Hochschule Hannover (MHH), konnte nun gemeinsam mit Wissenschaftlern von der University of Pennsylvania, USA, zeigen, dass bei etwa $20 \%$ der PPCM-Patientinnen ähnliche Mutationen wie bei der iDCM auftreten. Insgesamt identifizierten die Forscher dabei in 8 Genen Mutationen, die auch charakteristisch für die iDCM sind.

Beide Erkrankungen gehen mit einer ähnlichen Form der Herzschwäche einher. Im Gegensatz zur iDCM ist die Ursache für die PPCM aber bisher unbekannt. PPCM tritt ohne Vorwarnung im letzten Schwangerschaftsmonat oder in den ersten Monaten nach der Geburt auf. Binnen weniger Wochen kann diese Erkrankung zum schweren Herzversagen und sogar zum Tode führen. Eine von 1500 bis 2000 Schwangeren ist betroffen. Rechtzeitig erkannt ist die Herzschädigung der PPCMPatientinnen in der Regel mit Medikamenten behandelbar. Diese Frauen haben häufig eine schlechtere Prognose als PPCMPatientinnen ohne genetische Vorbelastung. Daher kann das Wissen um die Mutationen dem Arzt helfen, frühzeitig die richtige Therapie für die Patientin zu wählen.

Ware JS, Li J, Mazaika E. et al. (2016) Shared Genetic Predisposition in Peripartum and Dilated Cardiomyopathies. N Engl J of Med. 374:233-241

Quelle: Medizinische Hochschule Hannover 